\title{
Effects of Temperature, Substrate Concentration and pH on the Polycyclic Aromatic Hydrocarbon Pyrene Biodegradation by Arthrobacter sp. NJ5 Strain
}

\author{
I. Gailiūtè $\dot{1}^{1,2}$ G. Žèkaite் ${ }^{1}$, V. Čipinyté ${ }^{1}$, S. Grigiškis ${ }^{1}$, G. Dienys ${ }^{2}$ \\ 1 - JSC „Biocentras”, V. Graičiūno st. 10, LT 02241 Vilnius, Lithuania; Ph: + (370) 52661313 \\ fax: + (370) 526024 54,e-mail: biocentras@biocentras.lt \\ 2 - Vilnius University, Institute of Biotechnology, V. A.Graičiūno st. 8, LT 02241, Vilnius, Lithuania
}

\begin{abstract}
Polycyclic aromatic hydrocarbons (PAHs) are widely distributed in the environment and may persist for extended periods of time. PAHs are one of the most important classes of persistent organic contaminants. High molecular weight (HMW) PAHs (compounds containing four or more fused benzene rings) are generally recalcitrant to microbial attack. Until recently, only a few genera of bacteria have been isolated with the ability to utilize four-ring PAHs as sole carbon and energy sources. Because of the toxic, mutagenic, and carcinogenic characteristics of some, PAHs have been studied extensively by many scientists around the word. This paper presents research results, where 10 microbial strains belonging to genus Arthrobacter sp. and obtained from culture collection of JSC „Biocentras“ were tested for the best biodegradation of HMW PAH pyrene. Pyrene degradation experiments were conducted in liquid mineral medium. Pyrene concentration was $0.2 \mathrm{mg} / \mathrm{mL}$ at the beginning of degradation experiments. After $72 \mathrm{~h}$ incubation with ten Arthrobacter sp. strains, gas chromatography analysis revealed that highest pyrene degradation (19\%) was reached by Arthrobacter sp. NJ5 strain. The effect of medium $\mathrm{pH}$, pyrene concentration and temperature on the intensity of the degradation by the most active strain Arthrobacter NJ5 was investigated.
\end{abstract}

Keywords - Arthrobacter sp., biodegradation, pyrene, polycyclic aromatic hydrocarbons, (PAHs).

\section{INTRODUCTION}

Polycyclic aromatic hydrocarbons (PAHs) constitute a large and diverse class of organic compounds consisting of three or more fused aromatic rings in various structural configurations. The inertness, their low water solubility and strong lipophilic properties of these compounds lead to very high accumulation levels in the environment $[1,2]$. They have been detected in air, soil, sediments, surface water, ground water and road runoff $[3,4,5,6]$. Soil is the most important reservoir and reemission source of PAHs. Soil pollution with polycyclic aromatic hydrocarbons can have a bad influence on human health. Polycyclic aromatic hydrocarbons are resistant to degradation and can bioaccumulate through the food chain, so PAHs also may pose threat to human health over a long period [7]. These compounds enter the environment in many ways. PAHs and their derivatives are widespread products of incomplete combustion of organic materials arising, in part, from natural combustion such as forest, chemical fires and volcanic eruptions, but for the most part by human activities $[8,9,10,11,12]$. In recent decades the major sources of $\mathrm{PAH}$ pollution are industrial production, transportation, refuse burning, gasification and plastic waste incineration $[13,14,15,16]$.

Many PAHs are highly toxic, mutagenic, carcinogenic and teratogenic in nature; exposure to PAHs represents public health risks and raises environmental concerns $[17,18,19,20,21,22,23,24,25,26]$. Numerous studies have indicated that one-, two- and three-ring compounds are acutely toxic, while higher molecular weight PAHs are considered to be geotoxic [4].

Because many PAHs are so toxic there is a big interest in understanding the physicochemical processes and microbial degradation reactions that affect the mobility and fate of these compounds in groundwater and soil sediment systems.

When dissolved in water or adsorbed on particulate matter, PAHs can undergo photodecomposition upon exposure to ultraviolet light from solar radiation. In the atmosphere PAHs can react with pollutants such as ozone, nitrogen oxides and sulfur dioxide, generating diones, nitro- and dinitro-PAHs and sulfonic acids, respectively. PAHs may also be degraded by some microorganisms [1, 27] (Fig.1).

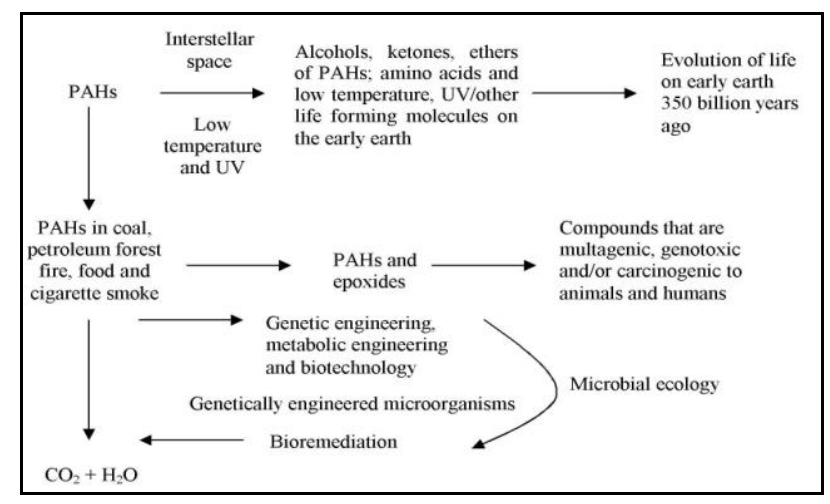

Fig. 1 Fate, toxicity and remediation of polycyclic aromatic hydrocarbons (PAHs) in environment [23] 
Photodegradation is an important degradation pathway in aquatic systems for high molecular weight PAHs. Photooxidation can chemically transform PAHs and the resulting products may be more carcinogenic and toxic than the parent compounds.

Volatilization plays an important role in the removal of low molecular weight PAHs from aquatic systems.

Biodegradation using microorganisms is usually the preferred and major route of $\mathrm{PAH}$ removal from contaminated environment because of some inherent advantages such as its cost effectiveness, the safest and comparatively better cleanup [17].

PAHs are subject to biodegradation by various microorganisms such as bacteria, fungi, and certain algae that live in soils, in sediment substrate, or are suspended in the water column [4, 28].

Site contamination with complex mixtures of organic compounds such as creosote, petroleum, or their combinations results in the selection of a mixed population of microorganisms with improved abilities to tolerate and extract energy from the contaminants [20, 28]. Among bacteria Xanthobacter, Serratia, Acitenobacter, Bacillus [24], Alcaligenes, Arthrobacter, Burkbolderia, Cychoclasticus, Pseudomonas [29, 30], Ralstonia, Nocardia, Rhodococcus, Sphinggomonas [31], Terrabacter, Mycobacterium [32] and among fungi Penicillium, Phanerochaete, Bjerkandera [12] and Trametes are the frequently identified microorganisms involved in PAH bioremediation [28, 33, 34].

\section{MATERIALS AND METHODS}

Polycyclic aromatic hydrocarbon

Pyrene $\left(\mathrm{C}_{16} \mathrm{H}_{10}\right)$ was obtained from Germany MerckSchuchardt Co. with a purity $>96 \%$. Pyrene has 4 benzene rings; molecular weight is 202.26; the octanolwater partition coefficient $\left(\log \mathrm{K}_{\mathrm{ow}}\right)$ is 4.88 [35].

Microorganisms

The following strains of hydrocarbon degrading bacteria belonging to genus Arthrobacter and obtained from culture collection of JSC „Biocentras“ were used: sp N3, NJ1, NJ5, NJ9, NJ6, Pr82, Mž811, K11, M1 and M2.

Media

Nutrient agar (Oxoid, Basingstone, UK) was used for plating microbial strains, and nutrient broth (Oxoid, Basingstone, UK) was used for the subculture and preculture of the strains. To investigate the ability of the strains to degrade pyrene, a mineral medium was used. The mineral medium had the following composition (g/L): $0.01\left(\mathrm{NH}_{4}\right)_{2} \mathrm{HPO}_{4} ; 0.2 \mathrm{NH}_{4} \mathrm{Cl} ; 0.25 \mathrm{~K}_{2} \mathrm{HPO}_{4} ; 0.25$ $\mathrm{KH}_{2} \mathrm{PO}_{4} ; 0.02 \mathrm{MnSO}_{4} ; 0.01\left(\mathrm{NH}_{4}\right)_{2} \mathrm{Fe}\left(\mathrm{SO}_{4}\right)_{2} * 6 \mathrm{H}_{2} \mathrm{O} ; 0.01$ $\mathrm{CaCl}_{2}$ and $0.05\left(\mathrm{CH}_{3} \mathrm{COO}\right)_{2} \mathrm{Zn}$.

Biodegradation of pyrene

The ability of the strains to degrade pyrene was investigated under sterile conditions in $250 \mathrm{~mL}$ flasks with $50 \mathrm{~mL}$ of mineral medium. Pyrene was used at a concentration of $0.2 \mathrm{mg} / \mathrm{mL}$. Pyrene was entered into the nutrient medium as a $10 \mathrm{mg} / \mathrm{mL}$ pyrene/hexane solution. Hexane has been evaporated while intensive mixing and heating in the temperature of $75^{\circ} \mathrm{C}$ temperature. Pyrene suspension in nutrient medium prepared with such method was used for experiments. Experimental flasks with $10 \%$ (v/v) of inoculum added and blank flasks were incubated in a rotary shaker at $30^{\circ} \mathrm{C}$ and $200 \mathrm{rpm}$. The effect of medium $\mathrm{pH}$, pyrene concentration and temperature on the intensity of the degradation by the most active strain was investigated under the same cultivation conditions.

Pyrene degradation dependency on medium $\mathrm{pH}$ was investigated at $\mathrm{pH}$ values of: $4 ; 5 ; 6 ; 7 ; 8$ and 9 .

Pyrene degradation dependency on temperature was evaluated at $5 ; 20 ; 25 ; 30 ; 35 ; 40{ }^{\circ} \mathrm{C}$; and dependency on concentration was investigated with $0.1 ; 0.2 ; 0.3 ; 0.4$; $0.6 ; 0.8 \mathrm{mg} / \mathrm{mL}$ of pyrene.

After $72 \mathrm{~h}$ incubation, pyrene was extracted with 20 $\mathrm{mL}$ of hexane from experimental and blank flasks.

GC analysis of pyrene

Samples were quantified with a GC system (GC-2010 Plus, Shimadzu, Japan) equipped with a flame-ionization detector and MXT-1 capillary column (Siltek treated stainless steel). Operation conditions were as follows: nitrogen was used as the carrier gas; the injector temperature and detector temperature were 330 and 350 ${ }^{\circ} \mathrm{C}$, respectively; the column oven temperature was kept at $40{ }^{\circ} \mathrm{C}$ for $1 \mathrm{~min}$ and then raised to $320{ }^{\circ} \mathrm{C}$ at a rate of $10{ }^{\circ} \mathrm{C} \mathrm{min}{ }^{-1}$.

Pyrene degradation intensity was calculated using the formula (1).

Degradation intensity $(\%)=\frac{\mathrm{c}_{\mathrm{O}}-\mathrm{c}_{\mathrm{x}}}{\mathrm{c}_{\mathrm{O}}} \times 100$

$\mathrm{c}_{0}$-pyrene concentration in blank flasks; $\mathrm{c}_{\mathrm{x}}$-pyrene concentration in experimental flasks.

\section{RESULTS AND DISCUSSION}

Pyrene has been used as a model compound to study biodegradation of high molecular weight polycyclic aromatic hydrocarbons because it is one of the sixteen toxic, mutagenic and carcinogenic PAHs, that have been considered as priority pollutants by US Environmental Protection Agency [28, 36] (Fig. 2).

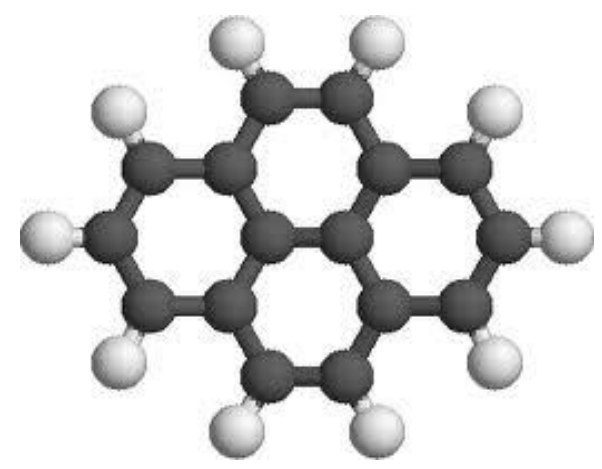

Fig.2 Structure of high molecular weight (HMW) polycyclic aromatic hydrocarbon pyrene $\left(\mathrm{C}_{16} \mathrm{H}_{10}\right)$ [37] 
After $72 \mathrm{~h}$ incubation with ten Arthrobacter strains in aerobic conditions in a rotary shaker, gas chromatography analysis revealed that the highest pyrene degradation was accomplished by Arthrobacter sp.NJ5 strain (Fig. 3), which was chosen for the later experiments.

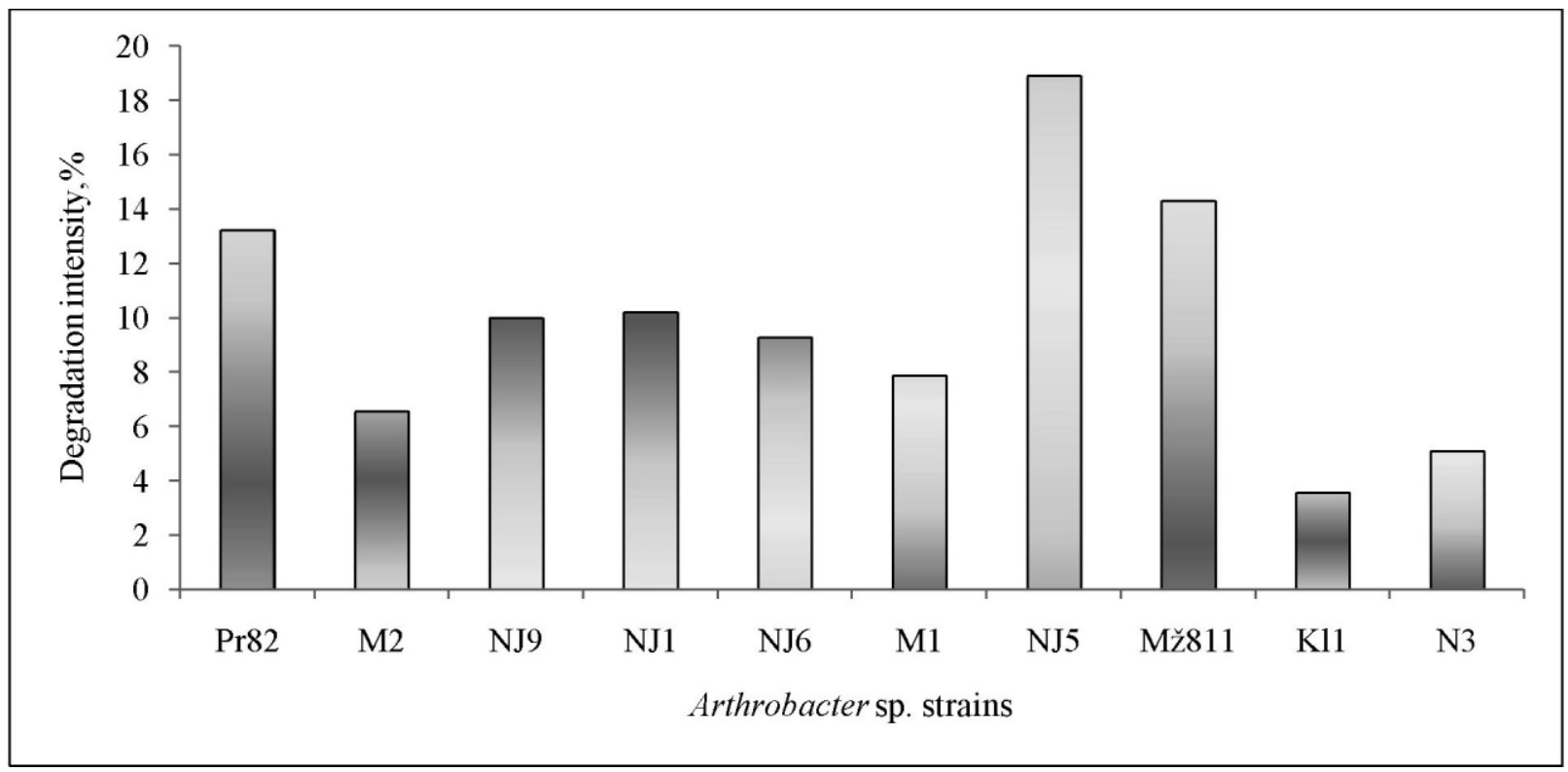

Fig.3 The effect of Arthrobacter sp. strains on pyrene biodegradation

Arthrobacter sp. NJ5 strain was isolated from clay contaminated with crude oil near Nefteyugansk in Russia.

The rate of degradation of hydrocarbons is mainly influenced by environmental limiting factors (salinity, nutrients, $\mathrm{pH}$, temperature, oxygen) and therefore may not be due to the enzymatic capacities of the endogenous hydrocarbon degrading bacterial strain $[38,39]$.

The effect of initial medium $\mathrm{pH}$, temperature and substrate concentration on pyrene degradation with Arthrobacter sp. NJ5 strain was investigated in this paper (Fig. 4; 5; 6). During the selection of an optimal medium $\mathrm{pH}$, the maximum substrate degradation was achieved at pH 7 (Fig. 4).

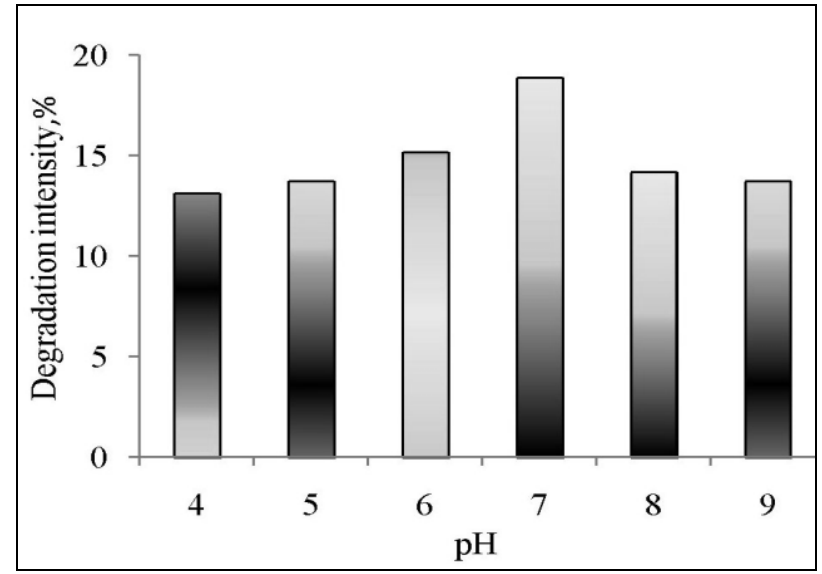

Fig. 4 Dependency of pyrene degradation by Arthrobacter sp. NJ5 strain on medium $\mathrm{pH}$
After determining the dependency of degradation on medium $\mathrm{pH}$, temperature regime was selected for the most efficient pollutant degradation. It was found that the rise in temperature from 5 to $35{ }^{\circ} \mathrm{C}$ promotes degradation of substrate and it is the highest at $35{ }^{\circ} \mathrm{C}$, however, degradation level drops at a temperature range of $35-40{ }^{\circ} \mathrm{C}$ (Fig. 5).

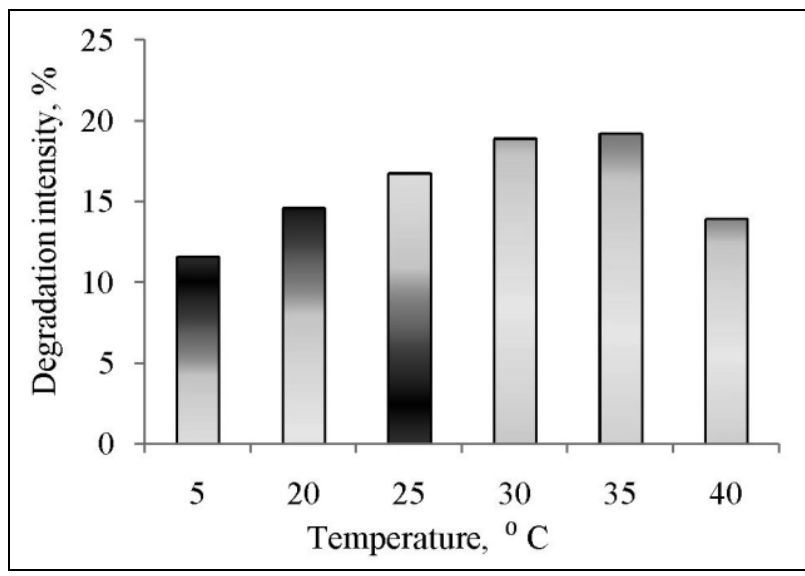

Fig. 5 Dependency of pyrene degradation by Arthrobacter sp. NJ5 strain on temperature

The effectiveness microbiological hydrocarbon degradation process is influenced by the substrate concentration as well, which can be inhibitory or even toxic to oil-oxidizing microorganisms [29, 40]. Therefore, the Arthrobacter sp. NJ5 strain oxidizing properties were tested against the polycyclic aromatic hydrocarbon substrate. Results revealed that, when substrate concentration in medium was increased from 


\section{Gailiūtė I., Žèkaitė G., Čipinytė V., Grigiškis S., Dienys G. EFFECTS OF TEMPERATURE, SUBSTRATE CONCENTRATION AND PH ON THE POLYCYCLIC AROMATIC HYDROCARBON PYRENE BIODEGRADATION BY Arthrobacter SP. NJ5 STRAIN}

0.1 to $0.4 \mathrm{mg} / \mathrm{mL}$, substrate degradation level has risen, but higher concentrations (up to $0.8 \mathrm{mg} / \mathrm{mL}$ ) slowed the intensity of degradation down. The best substrate degradation was observed when the initial pyrene concentration was $0.4 \mathrm{mg} / \mathrm{mL}$ (Fig. 6).

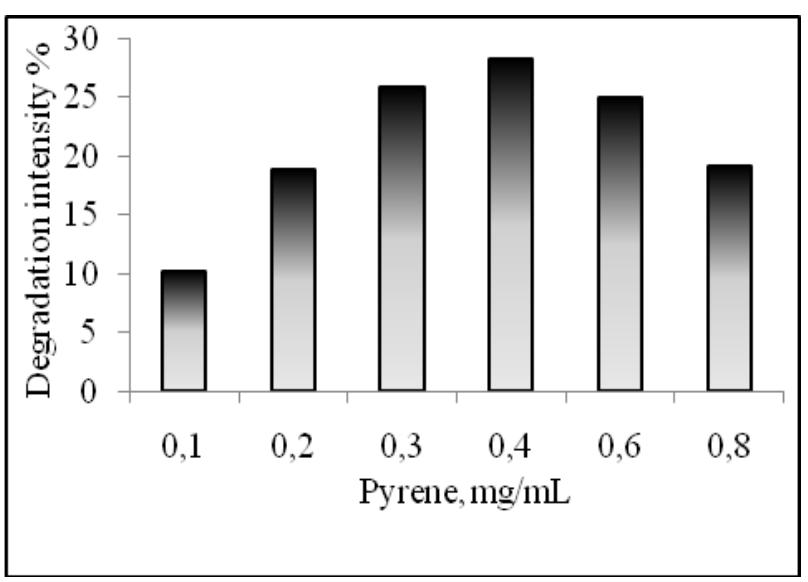

Fig. 6 Dependency of pyrene degradation by Arthrobacter sp. NJ5 strain on pyrene concentration

Results from previous experiment indicate that degradation of lower molecular weight polycyclic aromatic hydrocarbons is much easier. Experiments with antracene, where its concentration in the medium is $0.1 \mathrm{mg} / \mathrm{mL}$, achieved $51.8 \%$ degradation intensity of Arthrobacter sp. NJ5 within five hours [41]. Using the same concentration of pyrene, degradation intensity after 72 hours is only $10 \%$.

Gas chromatography analysis was carried out to investigate quantitative and qualitative changes of pyrene during biodegradation by the selected Arthrobacter sp. NJ5 strain (Fig. 7; Table 1). In biodegradation experiment initial concentration of pyrene and inoculate in mineral medium was 0.4 $\mathrm{mg} / \mathrm{mL}$ and $10 \%$, respectively. Inoculated flasks were incubated at $35{ }^{\circ} \mathrm{C}$ and $200 \mathrm{rpm}$ for $72 \mathrm{~h}$. Control test was performed at the same conditions, except for the inoculate.

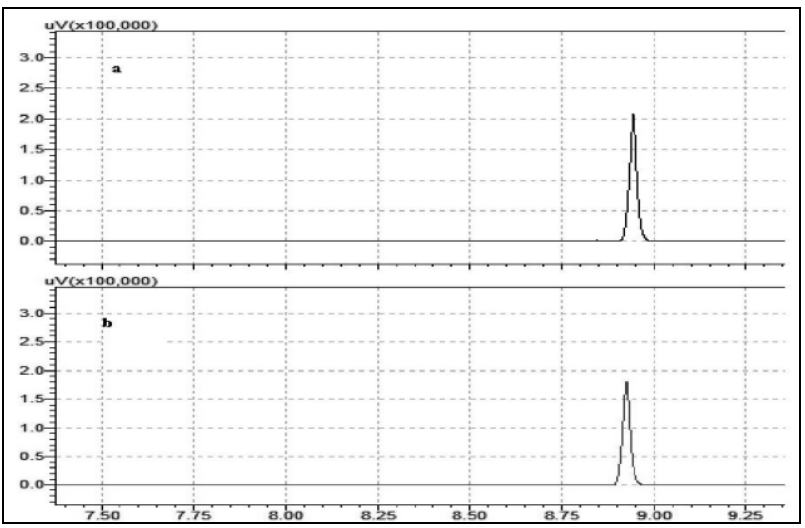

Fig. 7 Gas chromatograms of pyrene (a-control test; b-after biodegradation by Arthrobacter sp. NJ5 strain)
Gas chromatography data shows no qualitative structural changes of pyrene after biodegradation with Arthrobacter sp. NJ5 strain. According to lower pyrene peak plot it is considered that quantity of pyrene has changed during biodegradation.

TABLE 1.

QUANTITATIVE ANALYSIS OF PYRENE

\begin{tabular}{|l|l|l|l|l|}
\hline No & $\begin{array}{l}\text { Peak retention } \\
\text { time }\end{array}$ & $\begin{array}{l}\text { Peak } \\
\text { area }\end{array}$ & $\begin{array}{l}\text { Peak } \\
\text { height }\end{array}$ & $\begin{array}{l}\text { Concen- } \\
\text { tration }\end{array}$ \\
\hline $\mathrm{a}$ & 8.907 & 321111.6 & 208099.0 & 0.24384 \\
\hline $\mathrm{b}$ & 8.914 & 224021.1 & 104803.5 & 0.17609 \\
\hline
\end{tabular}

\section{CONCLUSION}

Among all 10 Arthrobacter strains used for experiments, Arthrobacter sp. NJ5 showed the best results in polycyclic aromatic hydrocarbon pyrene degradation.

The highest intensity of pyrene degradation by Arthrobacter sp. NJ5 strain occurred at the intial medium $\mathrm{pH}$ value of 7.0.

Temperature range of $30-35{ }^{\circ} \mathrm{C}$ was found to be the most optimal for pyrene biodegradation by Arthrobacter sp. NJ5 strain.

The highest substrate degradation level with Arthrobacter sp. NJ5 was reached, when the initial pyrene concentration was $0.4 \mathrm{mg} / \mathrm{mL}$, medium $\mathrm{pH}=7$ and temperature $30^{\circ} \mathrm{C}$.

\section{REFERENCES}

[1] Abd-Elsalam H. E.; Hafez E. E.; Hussain A. A.; Ali A. G.; ElHanafy A. A. Isolation and identification of three-rings polyaromatic hydrocarbons (anthracene and phenanthrene) degrading bacteria. American-Eurasian J. Agric \& Environ. Sci., 5(1). 2009, pp. 31-38.

[2] Shafiee, P.; Shojaosadati S. A. Biodegradation of polycyclic aromatic hydrocarbons by aerobic mixed bacterial culture isolated from hydrocarbon polluted soils. Iran J.Chem. Chem. Eng., 25(3). 2006, pp. 73-78.

[3] Desai A.; Vyas P. Petroleum and hydrocarbon microbiology. Applied Microbiology. 2006.

[4] Juhash A. L.; Naidu R. Bioremediation of high molecular weight polycyclic aromatic hydrocarbons: a review of the microbial degradation of benzo[a]pyrene. International Biodeterioration \& Biodegradation, 45. 2000, pp. 57-88.

[5] Mrozik A.; Piotrowska-Seget Z.; Labuzek S. Bacterial degradation and bioremediation of polycyclic aromatic hydrocarbons. Polish Journal of Environmental Studies, 12(1). 2003, pp. 15-25.

[6] Sack U.; Heinze T. M.; Deck J.; Cerniglia C. E.; Martens R.; Zadrazil F.; Fritsche W. Applied and Environmental Microbiology, 63. 1997, nr. 63, pp. 3919-3925.

[7] Lv J.; Shi R.; Cai Y.; Liu Y. Assesment of Polycyclic Aromatic Hydrocarbons (PAHs) Pollution in Soil of Suburbon Areas in Tianjin, China. Bull Environ Contam Toxicol, 85. 2010, pp. 5-9.

[8] Foght J. Anaerobic biodegradation of aromatic hydrocarbons: pathways and prospects. J. Mol Microbiol Biotechnol., 15. 2008, pp. 93-120.

[9] Perra G.; Renzi M.; Guerranti C.; Focardi E. 2009. Polycyclic aromatic hydrocarbons pollution in sediments: distribution and 


\section{Gailiūtė I., Žèkaitė G., Čipinytė V., Grigiškis S., Dienys G. EFFECTS OF TEMPERATURE, SUBSTRATE CONCENTRATION AND PH ON THE POLYCYCLIC AROMATIC HYDROCARBON PYRENE BIODEGRADATION BY Arthrobacter SP. NJ5 STRAIN}

sources in a lagoon system (Orbetello, Central Italy). Transit Water Bull., 3(1). 2009, pp. 45-58.

[10] Meharg A. A.; Wright J.; Osborn D. D. Polycyclic aromatic hydrocarbons $(\mathrm{PAH})$ dispersion and deposition to vegetation and soil following a large scale chemical fire. Environmenta Pollution, 99. 1998, pp. 29-36.

[11] Shuttlewoth K. L.; Cerniglia C. E.; Environmental aspects of $\mathrm{PAH}$ biodegradation. Applied Biochemistry and Biotechnology, 54. 1995, pp. 291-302.

[12] Valentin L.; Lu-Chau T. A.; Lopez C.; Feijoo G.; Moreira M. T.; Lema J. M. Biodegradation of dibenzothiophene, fluoranthene, pyrene and chrysene in soil slurry reactor by the white-rot fungus Bjerkandera sp. BOS55. Process Biochemistry, 42. 2007, pp. 641-648.

[13] Horng R. S.; Kuei C-H.; Chen W-C. Enhancement of aromatic hydrocarbon biodegradation by toluene and naphthalene degrading bacteria obtained from lake sediment: the effect of cosubstrates and cocultures. J. of Environmental Engineering, 135(9). 2009, pp. 854-860.

[14] Owabor C. N.; Ogbeide S. E.; Susu A. A. Model simulation of biodegradation of polycyclic aromatic hydrocarbon in a microcosm. Int. J. Environ. Res., 4(4). 2010, pp. 807-816.

[15] Kanaly R. A.; Harayama S. Biodegradation of high-molecularweight polycyclic aromatic hydrocarbons by bacteria. Journa of Bacteriology, 182(8). 2000, pp. 2059-2067.

[16] Seo J-S.; Keum Y-S.; Li Q. X.; Bacterial degradation of aromatic compounds. Int. J. Environ. Res. Public. Health, 6 2009, pp. 278-309.

[17] Hesham A.; E-L.; Alamri S. A.; Khan S.; Mahmound M. E.; Mahmound $H$. M. Isolation and molecular genetic characterization of a yeast strain able to degrade petroleum polycyclic aromatic hydrocarbons. African Journal of Biotechnology, 8(10). 2009, pp. 2218-2223.

[18] Kanaly R. A.; Harayama S. Advances in the field of highmolecular-weight polycyclic aromatic hydrocarbon biodegradation by bacteria. Microbial Biotechnology, 3(2) 2010, pp. 136-164.

[19] Li J-L; Chen B-H. Surfactant-mediated biodegradation of polycyclic aromatic hydrocarbons. Materials, 2. 2009, pp. 7694

[20] Phale P. S.; Basu A. Metabolic diversity in bacteria degradation of aromatic compounds. Journal of Integrative Biology, 11(3). 2007, pp. 252-279.

[21] Rodriguez S.; Bishop P. L. Enhancing the biodegradation of polycyclic aromatic hydrocarbons: effects of nonionic surfactant addition on biofilm function and structure. Journal of Environmental Engineering, 134(7). 2008, pp. 505-512.

[22] Roy R.; Ray R.; Chowdhury R.; Bhattacharya P. Degradation of polyaromatic hydrocarbons by mixed culture isolated from oil contaminated soil- A bioprocess engineering study. Indian Journal of Biotechnology, 5. 2007, pp. 107-113.

[23] Samanta S. K.; Singh O. V.; Jain R. K. Polycyclic aromatic hydrocarbons: environmental pollution and bioremedation. Trends in Biotechnology, 20(6). 2002, pp. 243-248.

[24] Zhao Z.; Wong J. W-C. Rapid biodegradation of benzo[a]pyrene by Bacillus subtilis BUM under thermophilic condition. Environmental Engineering Science, 27(11). 2010 , pp. 939-945.
[25] Vazquez-Duhalt R.; Westlake D. W. S.; Fedorak P. M. Lignin peroxidaze oxidation of aromatic compouns in systems containing organic solvents. Applied and Environmental Microbiology, 60(2). 1994, pp. 459-466.

[26] Xia, X.; Wang R. Effect of sediment particle size on polycyclic aromatic hydrocarbon biedegradation: importance of the sediment-water interface. Environmental Toxilogy and Chemistry, 27(1). 2008, pp. 119-125.

[27] Haritash A. K.; Kaushik C. P. Biodegradation aspects of polycyclic aromatic hydrocarbons (PAHs): a review. J. Of Hazardous material.,169. 2009, pp. 1-15.

[28] Khanna G. P.; Goyal D.; Khanna S. Pyrene biodegradation by Bacillus spp. Isolated from coal tar-contaminated soil. Bioremedation Journal, 15(1). 2011, pp. 12-25.

[29] Hasanuzzamana M.; Ueno A.; Ito H.; Ito Y.; Yamamoto Y.; Yumotoc I.; Okoyama H. Degradation of long-chain n-alkanes (C36 and C40) by Pseudomonas aeruginosa strain WatG. International Biodeterioration \& Biodegradation, 59. 2007, pp. 40-43.

[30] Zhang Z.; Zhaowei H.; Yang C.; Cuiqing M.; Tao F.; Xu P. Degradation of n-alkanes and polycyclic aromatic hydrocarbons in petroleum by a newly isolated Pseudomonas aeruginosa DQ8. Bioresourse Technology, 102.2011, pp. 4111-4116.

[31] Rentz J. A.; Alvarez P. J. J.; Schnoor J. L. Benzo[a]pyrene degradation by Sphingomonas yanoikuyae JAR02. Environmental Pollution, 151. 2007, pp. 669-677.

[32] Heitkamp M. A.; Freeman J. P.; Miller D. W.; Cerniglia C. E. Pyrene degradation by a Mycobacterium sp.: identification of ring oxidation and ring fission products. Applied and Environmental Microbiology 54(10). 1988, pp. 2556-2565.

[33] Cerniglia C. E.; Gibson D. T. Aromatic Hydrocarbons: degradation by bacteria and fungi. pp. 209-216.

[34] Mihelcic J. R.; Luthy R. Degradation of polycyclic aromatic hydrocarbon compounds under various redox conditions in soil-water systems. Applied and Environmental Microbiology, 54(5). 1988, pp. 1182-1187.

[35] Sabljic A.; Gusten H.; Verhaa H.; Hermens J. QSAR modelling of soil sorbtion. Improvements and systematics of $\log \mathrm{K}_{\text {oc }}$ vs. $\log \mathrm{K}_{\text {ow }}$ correlations. Chemosphere, 31. 1995, pp. 4489-4514.

[36] Fan S.; Li P.; Gang Z.; Ren W.; He N.; Promotion of pyrene degradation in rhizosphere of alfalfa (Medicago sativa L.). Chemosphere, 71. 2008, pp. 1593-1598.

[37] (http://astrochemistry.ca.astro.it/database/pyrene/pyrene.html)

[38] Aruzlazhagan P.; Vasudevan N.; Yeom I. T. Biodegradation of polycyclic aromatic hydrocarbon by a halotolerant bacterial consortium isolated from marine environment. Int. J. Environ. Sci. Tech., 7(4). 2010, pp. 639-652.

[39] Hurst C. J.; Sims R. C.; Sims J. L.; Sorensen D. L.; Mclean J. E.; Hulling S. Polycyclic aromatic hydrocarbon biodegradation as a function of oxygen tension in contaminated soil. Proceedings of the $10^{\text {th }}$ Annual Conference on Hazardous Waste Research.

[40] Okoh A. I. Biodegradation alternative in the cleanup of petroleum hydrocarbon pollutants. Biotechnology and Molecular Biology review, 2. 2006, pp. 38-50.

[41] Čipinytė V.; Grigiškis S. Naftą skaidančių mikroorganizmų atranka. Cheminè Technologija, 2(15) 2000. 